\title{
An Updated View of Leptin on Implantation and Pregnancy: A Review
}

\author{
M. HERRID ${ }^{1}$, S. K. A. PALANISAMY ${ }^{1}$, U. A. CILLER ${ }^{1}$, R. FAN ${ }^{2}$, P. MOENS ${ }^{1}$, \\ N. A. SMART ${ }^{1}$, J. R. MCFARLANE ${ }^{1}$ \\ ${ }^{1}$ Centre for Bioactive Discovery in Health and Aging, University of New England, Armidale, \\ Australia, ${ }^{2}$ College of Animal Science and Veterinary Medicine, Shanxi Agricultural University, \\ Taigu, China
}

Received October 1, 2013

Accepted February 28, 2014

On-line June 5, 2014

\section{Summary}

The hormone leptin, which is thought to be primarily produced by adipose tissue, is a polypeptide that was initially characterized by its ability to regulate food intake and energy metabolism. Leptin appears to signal the status of body energy stores to the brain, resulting in the regulation of food intake and whole-body energy expenditure. Subsequently, it was recognized as a cytokine with a wide range of peripheral actions and is involved in the regulation of a number of physiological systems including reproduction. In the fed state, leptin circulates in the plasma in proportion to body adiposity in all species studied to date. However other factors such as sex, age, body mass index (BMI), sex steroids and pregnancy may also affect leptin levels in plasma. In pregnant mice and humans, the placenta is also a major site of leptin expression. Leptin circulates in biological fluids both as free protein and in a form that is bound to the soluble isoform of its receptor or other binding proteins such as one of the immunoglobulin superfamily members Siglec-6 (OB$\mathrm{BP} 1)$. Although the actions of leptin in the control of reproductive function are thought to be exerted mainly via the hypothalamicpituitary-gonadal axis, there have also been reports of local direct effects of leptin at the peripheral level, however, these data appear contradictory. Therefore, there is a need to summarize the current status of research outcomes and analyze the possible reasons for differing results and thus provide researchers with new insight in designing experiments to investigate leptin effect on reproduction. Most importantly, our recent experimental data suggesting that reproductive performance is improved by decreasing concentrations of peripheral leptin was unexpected and cannot be explained by hypotheses drawn from the experiments of excessive exogenous leptin administration to normal animals or $o b / o b$ mice.

\section{Key words}

Leptin • Implantation • Pregnancy

\section{Corresponding author}

J. McFarlane, University of New England, Armidale NSW 2350 Australia. E-mail: jmcfarla@une.edu.au

\section{Introduction}

Reproductive performance in many species involves various diverse factors, including nutrition, with these effects likely to be mediated via endogenous endocrine influences (Cunningham et al. 1999). To date, the mechanistic links between nutrition and the reproductive axis have not been clearly elucidated.

Leptin was identified as a peripheral satiety signal belonging to the helical cytokine family which crosses the blood brain barrier and signals to the hypothalamus regulating energy expenditure and appetite (Zhang et al. 1994). Although it was originally thought to be derived predominantly from adipose tissue, leptin is now known to be produced in many tissues. Leptin circulates in plasma bound to a number of binding proteins such as one of the immunoglobulin superfamily members Siglec-6 (Patel et al. 1999) and a soluble form of the leptin receptor (Liu et al. 1997). Although there is some evidence that these proteins regulate the bioavailability of leptin (Lou et al. 2010), the role of 
these binding proteins remains unclear and there has been little work in recent years investigating their function. Further studies have revealed that leptin actually appears to be almost ubiquitously expressed in many tissues and has a multitude of possible functions including a direct role in reproduction.

The complete absence of leptin is not developmentally lethal and in mice results in early onset obesity, stunted skeletal and brain growth, extreme insulin resistance, hyperphagia, a compromised immune system and infertility (Ingalls et al. 1950, Ohtake et al. 1977). A similar profile is seen in the relatively few human individuals who have been identified as leptin deficient (Montague et al. 1997). After the discovery of leptin it was quickly discovered that leptin deficiency was not responsible for the worldwide rising obesity prevalence (Arch et al. 1998, Caro et al. 1996) rather leptin concentrations were closely correlated to BMI
(Tungtrongchitr et al. 2000), thus leading to the concept of leptin resistance. The morbidly obese (ob/ob) mouse (Ingalls et al. 1950) discovered many decades ago was found to be leptin deficient (Zhang et al. 1994) and thus has been used to inform much of today's research. There is increasing evidence that, in addition to its action on food intake and energy expenditure, leptin plays an important role in many other systems including reproduction and development (Cunningham et al. 1999, Holness et al. 1999). Fertility can be restored in both female and male $o b / o b$ mice by the exogenous provision of leptin, which is characterized by an increase in basal LH and FSH (Chehab 1996, Mounzih et al. 1997). However, fertility of $o b / o b$ mice is not reversed simply by food restriction (Chehab 1996, Mounzih et al. 1997), indicating an effect of leptin per se on reproductive function.

Table 1. Leptin effects on female reproduction.

\begin{tabular}{|c|c|c|c|c|c|}
\hline Action site & $\begin{array}{c}\text { Target cells and } \\
\text { organs }\end{array}$ & Biological process & Biological functions & Mechanism & References \\
\hline \multirow[t]{2}{*}{$\begin{array}{l}\text { Central nervous } \\
\text { system }\end{array}$} & Hypothalamus & GnRH secretion & $\begin{array}{l}\text { Regulation of LH and } \\
\text { FSH secretion }\end{array}$ & $\begin{array}{l}\text { Indirectly via } \\
\text { kisspeptin }\end{array}$ & $\begin{array}{l}\text { Quennell et al. } \\
2009\end{array}$ \\
\hline & Pituitary & $\begin{array}{l}\text { Estrous cycles and } \\
\text { ovulation }\end{array}$ & $\begin{array}{l}\text { FSH and LH release; } \\
\text { LH plasticity and } \\
\text { cyclicity }\end{array}$ & & $\begin{array}{l}\text { Barash et al. } \\
\text { 1996, Carro et } \\
\text { al. } 1997\end{array}$ \\
\hline \multirow[t]{4}{*}{$\begin{array}{l}\text { Peripheral } \\
\text { system }\end{array}$} & Ovary & $\begin{array}{l}\text { Ovarian } \\
\text { steroidogenesis }\end{array}$ & Estrogen production & $\begin{array}{l}\text { P450 aromatase; } \\
\text { P450-17 } \alpha \\
\text { hydroxylase }\end{array}$ & $\begin{array}{l}\text { Zamorano et al. } \\
1997\end{array}$ \\
\hline & & Folliculogenesis & $\begin{array}{l}\text { Low leptin promotes } \\
\text { follicle development }\end{array}$ & $\begin{array}{l}\text { Promotes the } \\
\text { transition of } \\
\text { primordial to } \\
\text { primary follicles }\end{array}$ & $\begin{array}{l}\text { Panwar et al. } \\
2012\end{array}$ \\
\hline & Embryo & Embryogenesis & $\begin{array}{l}\text { Biophysical effect on } \\
\text { embryo growth and } \\
\text { quality }\end{array}$ & $\begin{array}{l}\text { Stimulates } \\
\text { proliferation }\end{array}$ & $\begin{array}{l}\text { Herrid et al. } \\
2006\end{array}$ \\
\hline & Uterus & Angiogenesis & $\begin{array}{l}\text { Stimulates } \\
\text { metalloproteinase } \\
\text { activity }\end{array}$ & $\begin{array}{l}\text { Inhibits terminal } \\
\text { differentiation of } \\
\text { committed giant } \\
\text { cells }\end{array}$ & $\begin{array}{l}\text { Schulz et al. } \\
2009\end{array}$ \\
\hline
\end{tabular}

Leptin signaling is through a single transmembrane protein which is a member of the gp130 family of cytokine receptors (Tartaglia et al. 1995). The receptor occurs in at least 6 splice variants (obRa-f), all of 
which have an intact extracellular binding domain but different intracellular domains. ObRe is comprised of just the extracellular domain and is a major leptin binding protein in circulation. The only full length receptor $\mathrm{ObRb}$ is thought to be the predominant isoform involved in the intracellular signal transduction via the JAK/STAT pathway (Magkos et al. 2011). Its importance is demonstrated in the diabetic mouse $(d b / d b)$ which lacks a functional $\mathrm{ObRb}$ resulting in a similar phenotype to the $o b / o b$ mouse. It is likely that the short form receptors (other than ObRe) which have only one of the two JAK binding domains (box 1) are also capable of signaling perhaps by partial activation JAK2. However their role may be more subtle with a recent study showing the ObRa knockout (KO) mouse is fertile and does not get obese however it does have some slight but significant dysfunction in response to a high fat diet (Li et al. 2013). Leptin may also be involved in a number of other pathways such as PI3K and MAPK, although the mechanism is less well understood (Fruhbeck 2006). It has also been shown that leptin binding to the receptor induces dimerization and heteromerization between the different isoforms has also been reported (Bacart et al. 2010, White and Tartaglia 1999). Consequently, the role of the short isoforms of the receptor which are very abundant in many tissues remains unclear.

Leptin has a significant permissive role in the physiological regulation of several neuroendocrine axes, such as hypothalamic-pituitary-gonadal, -thyroid, -growth hormone, and -adrenal axes (Khan et al. 2012, Mantzoros et al. 2011), but there is evidence that excessive concentrations of leptin have negative effects on reproduction. The current review focuses on the role of leptin plays on reproduction via: 1) the hypothalamicpituitary axis; 2) a direct peripheral effect on a variety of reproductive cells or organs, such as embryo, ovary, uterus and placenta (Table 1).

\section{The effect of leptin on implantation and pregnancy}

Leptin appears to modulate female reproductive physiology at multiple levels through central, peripheral and local regulation.

\section{Leptin and hypothalamus-pituitary (HP) axis}

\section{Hypothalamus}

Leptin receptor/s mRNA have been localized in various cell types of the mouse (White et al. 2000), rat (Funahashi et al. 2000), and ovine hypothalamus (Iqbal et al. 2001). Additionally, not only the leptin receptor mRNA but also leptin protein mRNA has been found to be expressed in rat hypothalamus (Morash et al. 1999, 2003). Recent studies using advanced technologies has shown that hypothalamic gonadotropin-releasing hormone (GnRH) neurons do not express the long form of leptin receptor $(\mathrm{Ob}-\mathrm{Rb})$ thus leptin does not appear to act directly on GnRH neurons to regulate fertility, at least, in rats and mice (Quennell et al. 2009). Although its cellular targets and molecular mechanisms of action remain to be fully elucidated, leptin effects on hypothalamic neuropeptides play a pivotal role in the maintenance of energy homeostasis and reproduction. To date, the $\mathrm{Ob}-\mathrm{Rb}$ mRNA has been identified in the arcuate and ventromedial nuclei of hypothalamus in all species studied (Finn et al. 1998) - two areas responsible for both feeding and reproductive functions. The effects of leptin on GnRH are mediated through interneuronal pathways involving neuropeptide-Y (NPY), pro-opiomelanocortin (POMC), cocaine-and amphetamine-regulated transcript (CART), corticotrophin releasing factor (CRF) and orexin, CRF and kisspeptin.

It is relatively well documented that leptin's central action is mediated via hypothalamic NPY gene expression (Hakansson et al. 1996, Schwartz et al. 1996). In response to energy restriction or fasting, it is proposed that NPY gene expression increases in response to a reduction in circulating leptin levels. In support of this hypothesis, $\mathrm{Ob}-\mathrm{Rb}$ is coexpressed in NPY neurons in the arcuate nucleus of the hypothalamus in mice (Mercer et al. 1996a, b), and sheep (Dyer et al. 1997a). The increase in NPY production has been postulated to decrease the stimulatory input to downstream neural pathways that ultimately reach the GnRH neurons (Campfield and Smith 1998, Yu et al. 1997a). The evidence for neuroendocrine effects of leptin on GnRH release is convincing. Increased gonadotropin secretion consistently occurs as a result of leptin treatment in $o b / o b$ mice and undernourished animals, presumably removing the inhibition of GnRH release by NPY (Barash et al. 1996, Chehab et al. 1996).

However, hypothalamic NPY is not the only central nervous system (CNS) target for leptin, since NPY knockout mice have normal food intake and body weight. Additionally, these mice are also fertile and respond to leptin treatment (Erickson et al. 1996, Schwartz et al. 1998), consequently it has been postulated 
that this system is not critical for mediating the reproductive effects of leptin. In support of this concept, the incubation of leptin and NPY with hypothalamic explants from adult rats revealed that leptin and NPY show a separate permissive effect on GnRH secretion in the adult rat hypothalamus (Lebrethon et al. 2000, Parent et al. 2000). In both sexes, NPY is predominantly involved in the control of the frequency of pulsatile GnRH secretion through the Y5 receptor subtype, while leptin affects GnRH pulse amplitude via the modulation of the CART (a hypothalamic inhibitor of food intake) (Lebrethon et al. 2000, Parent et al. 2000). Thus the contribution of leptin to GnRH secretion could involve both an action on NPY and another neuroendocrine pathway such as the leptin-CART axis.

In addition to NPY, leptin receptor is also colocalized with other neuropeptides within the hypothalamus such as pro-opiomelanocortin (POMC), CART, CRF and orexin (Elias et al. 1999, Hakansson and Meister 1998). POMC, the precursor protein of the endogenous ligand of the melanocortin system, $\alpha$ melanocyte-stimulating hormone, is one of the potential mediators of leptin in the hypothalamus (Lin et al. 2001). POMC gene expression is regulated by leptin in a manner opposite to that of NYP, with the expression is decreased in the arcuate nucleus of $o b / o b$ mice than in lean normal mice or with fasting (Thornton et al. 1997). Leptin receptors are co-expressed in POMC neurons and leptin treatment reduced feed intake and increased POMC mRNA levels in ob/ob mice (Thornton et al. 1997). Furthermore, genetic POMC deficiency leads to an obesity syndrome in both mice and humans (Tritos and Mantzoros 1997). Neurons containing POMC are located in areas within the hypothalamus that are involved in GnRH secretion and feed intake regulation in the pig (Kineman et al. 1989, 1988), and cattle (Leshin et al. 1995). Therefore the interaction between POMC and leptin is likely to be an important signaling pathway in the regulation of body weight and the secretion of $\mathrm{GnRH}$ (Lin et al. 2001).

\section{Pituitary}

With respect to the leptin action on pituitary, using immunohistochemistry and RT-PCR, Jin et al. (1999, 2000) have demonstrated the presence of leptin and $\mathrm{OB}-\mathrm{Rb}$ in human, mice and rat pituitary tissue. Leptin was present in 20-25\%,7\%, and $5 \%$ of human, mouse, and rat anterior pituitary cells, respectively. The cells expressing leptin in humans were colocalized with
ACTH staining cells $(70 \%)$, with a lesser percentage in cells expressing growth hormone $(\mathrm{GH})$, thyroidstimulating hormone (TSH), and FSH/LH (Jin et al. 1999). However, in rat and mouse pituitary, TSH producing cells were the predominant cell type expressing leptin, with only a small percentage of LH and FSH cells colocalized with leptin (Jin et al. 2000). The differences in cell type expressing leptin in humans and rodents may result in a species variation of leptin regulation in the pituitary. Leptin receptor mRNA has been found in rodent pituitary (Jin et al. 2000), human foetal pituitary (Jin et al. 1999, Shimon et al. 1998) and ovine anterior pituitary (Dyer et al. 1997b, Iqbal et al. 2001). In vitro studies showed that release of LH and FSH from rat anterior pituitary in response to increasing doses of leptin was bell-shaped dose-response (Yu et al. 1997a) indicating stimulatory effects at low concentrations and inhibitory effects at higher doses. In ovariectomized, estrogen primed rats, leptin significantly increased plasma LH, whereas, it had no effect on plasma FSH concentrations (Yu et al. 1997a). The above results suggesting that leptin may control the gonadotropes function both by action at the hypothalamic level on the HP axis, and by direct action in the pituitary itself (Hausman et al. 2012).

\section{Leptin and its effects on peripheral tissue}

\section{Leptin and ovary (oocytes)}

Ovarian follicle development is a complex process that begins with the establishment of a finite pool of primordial follicles and culminates in either the atretic degradation of the follicle or the release of a mature oocyte for fertilization (Amleh and Dean 2002). Fluctuations in leptin levels occur naturally in the estrous cycle in rats (Fungfuang et al. 2013) and during the menstrual cycle in women, with lower circulating concentrations during the follicular phase and higher levels during the luteal phase (Cella et al. 2000, Quinton et al. 1999).

The identification of leptin receptor expression (ObRb, ObRa and ObRe) in gonads (Fei et al. 1997, Herrid et al. 2006, Herrid et al. 2008a) and the demonstration of leptin effects on steroidogenesis in in vitro systems (Spicer and Francisco 1997, Zachow and Magoffin 1997), suggest that leptin also has direct effects on downstream endocrine targets of the reproductive axis. Indeed, it has been shown that leptin receptor mRNA (ObRb and ObRa) is expressed in human (Karlsson et al. 
1997), pig (Ruiz-Cortes et al. 2000) and mouse ovary (Ryan et al. 2002). More recent work has demonstrated that $\mathrm{ObRb}$ is expressed in both granulosa and thecal cells in the pig (Smolinska et al. 2013).

In vitro studies on thecal and granulosa cells of different animal species have shown that leptin has a negative effect on ovarian steroidogenesis. Leptin modulates the combined gonadotropin and insulin or insulin-like growth factor (IGF) stimulated steroidogenesis in bovine (Spicer et al. 2000, Spicer and Francisco 1997), and rat (Almog et al. 2001) cells. Leptin also has an inhibitory effect on early follicular development in both immature and adult mice (Kikuchi et al. 2001), but in contrast to the inhibitory effects of leptin on ovarian steroidogenesis, a stimulatory effect has also been reported by way of a marked increase in estrogen production in the ovary when $o b / o b$ mice were treated with recombinant leptin (Zamorano et al. 1997).

Leptin protein is found in human follicular fluid, with levels corresponding to those found in serum (Cioffi et al. 1997, Karlsson et al. 1997). Data concerning follicular leptin concentration with oocyte maturation and embryo development are controversial. Patients who become pregnant from in vitro fertilization IVF had lower mean follicular fluid concentration of leptin than nonpregnant patients (Mantzoros et al. 2000). Follicular fluid leptin concentrations demonstrated a negative correlation with embryo quality in IVF patients (Barroso et al. 1999), while an association between follicular leptin concentration and embryo development was not observed in a separate IVF program (Cioffi et al. 1997).

Interestingly, mice treated with anti-leptin and gonadotropins had a significantly $(\mathrm{P}<0.05)$ higher number of Graafian follicles in their ovaries compared with ovaries in the control and gonadotropin alone group, this indicates that peripheral leptin may act as an inhibitor of ovarian follicle development (Panwar et al. 2012). Passive immunization against leptin in sheep results in an acute increase in ovarian estradiol secretion during follicular phase (Kendall et al. 2004), while high leptin concentration in the ovary suppresses estradiol production and interfere with the development of dominant follicles and oocytes maturation (Mantzoros 2000).

\section{Leptin and embryos}

Leptin has been detected by immunofluorescence in meiotically mature mouse, human, pig and bovine oocytes and early cleavage embryos (Cioffi et al. 1997, Kim et al. 2006). Moreover, leptin mRNA and protein has been identified in human and mouse blastocysts and hatched blastocysts (Gonzalez RR et al. 2000, Kawamura et al. 2003, 2002). However, using conventional and real-time PCR, our and other studies indicated that leptin mRNA is not expressed in mouse 2, 4, 8-cell and blastocyst stages embryos (Herrid et al. 2006, Schulz and Roberts 2011), whereas three isoforms of leptin receptor (Ob-Ra, Ob-Rb and Ob-Re) were identified in these cells, indicating that leptin is likely to modulate embryo development via a paracrine signaling system (Herrid et al. 2006). Therefore leptin presence in oocyte and embryos are maternal origin, which is differentially distributed among the blastomeres of pre-implantation embryos to create a polarized pattern (Antczak et al. 1997, Schulz and Roberts 2011).

Leptin has a concentration and developmental stage-dependent effect on early mouse embryo development. The requirement of leptin for embryo development changes during the gestational period, with lower levels being beneficial to development at early embryogenesis and higher levels at later stages. Leptin improves early embryonic development at physiological concentrations, while it exerts an inhibitory effect on the 2-cell and 4-cell stage embryos developing into advanced stages at supraphysiological dose when cultured in vitro. However, the inhibitory impact of high leptin concentration on embryo development was diminished by the 8-cell stage (Herrid et al. 2006). The mechanism by which leptin regulates early embryonic development may be due to its effect in promoting cell proliferation. It has also been reported that leptin increased the total cell number of blastocysts, especially the trophectoderm (ET) cells, which are necessary for implantation and form the placenta and extra-embryonic membranes (Craig et al. 2005, Kawamura et al. 2002). Indeed, the addition of leptin into culture medium shortened the time required to develop from the 8-cell stage to blastocysts (Herrid et al. 2006).

\section{Leptin and uterus}

The identification of the long form of leptin receptor protein expression in the human uterus (Alfer $e t$ al. 2000, Gonzalez RR et al. 2000) and the effect of leptin on steroid production in the ovary (Spicer et al. 2000, Zachow et al. 1999) suggests a relevant regulatory capacity of leptin in endometrial transformation and differentiation. Leptin and $\mathrm{Ob}-\mathrm{Rb}$ protein were identified in human secretory endometrium and in cultured 
endometrial epithelial cells (EECs) by RT-PCR, western blot and immunohistochemistry (Gonzalez RR et al. 2000). In the pregnant mouse, the levels of leptin in the uterine fluid are higher than those in non-pregnant mouse as measured by ELISA (Kawamura et al. 2002).

In humans, the leptin receptor protein was shown to be expressed in glandular and luminal epithelium and is periodically regulated throughout the menstrual cycle, peaking in the early secretory phase (Alfer et al. 2000, Kitawaki et al. 2000). Although the exact reason for the variation in leptin receptor mRNA abundance during the menstrual cycle remains unclear, there does appear to be a link between the expression of this gene and ovarian steroids. In one study, in vitro cultures of human proliferative endometrium with progesterone suppressed $\mathrm{Ob}-\mathrm{Rb}$ mRNA expression by $50 \%$, but not from the secretory endometrium (Koshiba et al. 2001).

\section{Leptin and implantation}

The first study investigating the dependence of pregnancy on leptin in the $o b / o b$ mice revealed that a human recombinant leptin injection daily intraperitoneally (i.p.) at a dose of $50 \mu \mathrm{g} / \mathrm{g}$ body weight to adult $o b / o b$ female mice restored fertility. Withdrawal of leptin treatment from the pregnant females at $0.5,6.5$, 10.5 and 19.5 days post coitum did not affect any stage of the pregnancy (Mounzih et al. 1997). From these findings it was concluded that conception, implantation, fetal growth and parturition are not dependent on the presence of leptin (Mounzih et al. 1997). A similar study reported contrasting results with regard to the leptin requirement during early pregnancy. In this study, adult $/ o b$ males and females were injected with the murine recombinant leptin at a concentration $0.5 \mu \mathrm{g} / \mathrm{g}$ body weight twice a day for 8 days and then they were mated together, and the dose was reduced to $0.5 \mu \mathrm{g} / \mathrm{g}$ once a day. Pregnancy did not result when treatment was stopped at 0.5 or 3.5 days post coitum, while the withdrawal of leptin treatment at 6.5 or 14.5 did not affect normal pregnancy and parturition, suggesting that leptin is essential for normal preimplantation and implantation processes (Malik et al. 2001). The differing results obtained in the two studies were discussed by Malik et al. (2001) and they presumed that the high dose leptin $(50 \mu \mathrm{g} / \mathrm{g})$ used in the first study may have led to an accumulated reserve of leptin sufficient to compensate for the leptin requirement of a successful early pregnancy.

Indeed, leptin increases the total cell number of blastocysts, especially the ET cells, which are necessary for implantation and form the placenta and extraembryonic membranes (Craig et al. 2005, Herrid et al. 2006, Kawamura et al. 2002). In addition, intrauterine injections of a leptin antagonist blocks implantation (Ramos et al. 2005). Cell culture experiment using mouse trophoblastic giant cells showed that leptin maintains trophoblast cells at an intermediary stage of differentiation and thus increases their invasiveness during implantation process (Schulz et al. 2009). On the other data from our laboratory suggests that lowering leptin in circulation using antibodies increases implantation rates in mice (Panwar et al. 2014).

\section{Leptin and pregnancy}

The circulating pattern of leptin in rodents and healthy pregnant women has been established by several studies. It appears that the maternal circulating leptin levels rise in both rodents (Chien et al. 1997, Gonzalez LC et al. 2000) and humans (Hardie et al. 1997) during pregnancy, especially in the second and third trimesters, with a significant fall at around birth. In contrast, a study conducted by Terada et al. (1998) showed the maternal circulating leptin levels are stable during early- and midpregnancy and decline during late pregnancy in the rat. Similar results have also been observed in sheep (Thomas et al. 2001).

The main source of this increase may be the placenta (Dotsch et al. 1999, Hardie et al. 1997, Masuzaki et al. 1997) in humans but it has not been established whether placenta-derived leptin would affect the circulating levels of this hormone during pregnancy in rodents, despite leptin mRNA being expressed in placenta (Hoggard et al. 1997, Terada et al. 1998). However, leptin mRNA expression was not detected in pregnant mouse placenta, whereas the level of leptin mRNA in adipose tissue increased 3- to 5-fold on days 13 and 17 of pregnancy compared with that of virgin mouse, which roughly matches with the increase of serum leptin levels in pregnant mice from days 11 to day 17 of pregnancy (Tomimatsu et al. 1997). It also has been reported that there is no peak in circulating leptin towards the end of pregnancy in the adolescent ewe, with the placenta leptin concentration appearing negligible. In this animal model, a nutritional switch-over experiment revealed that leptin mRNA and protein in perirenal adipose tissue were higher in overfed animals (Thomas et al. 2001). In aggregate, the elevated maternal leptin levels seem to be primarily due to the increased leptin production by 
adipose tissue.

The secretion of the soluble form of leptin receptor $(\mathrm{Ob}-\mathrm{Re})$ into the maternal circulation (Gavrilova et al. 1997, Lewandowski et al. 1999) or the changes in the levels of hormones which might stimulate leptin secretion (e.g. insulin, estrogens and hCG) (Sivan et al. 1998) may contribute to hyperleptinemia during pregnancy. However, the high maternal leptin concentrations during pregnancy are associated with a leptin resistant state as there is no decrease in food intake or change in energy expenditure (Holness et al. 1999) and the functional reason for raised leptin is not yet fully determined. It has been suggested that this physiological resistance to the high levels of leptin is due, at least in part, to a decrease in the expression of $\mathrm{Ob}-\mathrm{Rb}$, the biologically active form of leptin receptor, in the hypothalamus during pregnancy in the rat (Garcia et al. 2000).

In addition to being a site of leptin synthesis, the placenta is a site of abundant Ob-R expression of both the long signaling $(\mathrm{Ob}-\mathrm{Rb})$ and short transporting isoforms (Ob-Ra) (Ashworth et al. 2000, Hoggard et al. 2001, 1997). Thus, it is possible that placenta-derived leptin might have a paracrine and/or autocrine role in placentafetal physiology. Other authors have suggested that placenta-derived leptin might act as an important growth factor for the fetus and/or a signal of energy status between mother and fetus (Hassink et al. 1997, Hoggard et al. 1997). Whatever may be the role of leptin during pregnancy, the requirement for leptin during early implantation seems to be more important than during the mid to late stages.

Leptin is not necessary to maintain an established pregnancy in the ob/ob mice (Malik et al. 2001, Mounzih et al. 1997), the physiological significance of the elevation of maternal leptin levels during late gestation is a mystery. This increase could be explained by the secretion of $\mathrm{Ob}-\mathrm{Re}$ from the placenta which in the mouse, secretes a large amount of Ob-Re during late pregnancy resulting in a significant increase in serum leptin levels (Gavrilova et al. 1997).

Circulating leptin concentrations reportedly increase during gonadotropin stimulation for IVF, apparently enhanced by the high estradiol concentrations experienced during IVF cycles (Butzow et al. 1999, Zhao et al. 2000). Significantly lower concentrations of leptin were observed in women who subsequently miscarried in an IVF program (Laird et al. 2001). Similarly, women with a successful pregnancy had higher concentrations of leptin at 12 days after embryo transfer than those who miscarried (Unkila-Kallio et al. 2001), thus suggesting that leptin may play a role in preventing miscarriage. However, the serum leptin to body mass index (BMI) ratio was more strongly correlated with pregnancy success than was leptin alone (Brannian et al. 2001). Moreover, women with a low leptin:BMI ratio had significantly more superior quality embryos on day 3 post-retrieval and a greater implantation rate than women with a high leptin:BMI ratio (Brannian et al. 2001). These results seem to suggest that the requirement of leptin for a successful pregnancy changes during the gestational period, with lower levels being beneficial to implantation at early pregnancy and perhaps higher levels at later stages.

Interestingly, the administration of exogenous leptin to pregnant mice during food restriction did not increase the pregnancy rate, but had greater negative impacts on offspring health than food restriction alone, indicating that importance of low leptin in the physiological response to energy restriction (Schulz et al. 2012).

\section{Leptin resistance}

Leptin resistance has been reported in a range of physiological conditions such as pregnancy (Henson and Castracane 2000), early development (Mistry et al. 1999) and human obesity (Houseknecht et al. 1998). In fact, with the exception of the ob/ob mouse and a few individuals from a limited number of families (Montague et al. 1997), all models of rodent and human obesity studied are characterized by hyperleptinemia, and not by leptin deficiency (Arch et al. 1998, Caro et al. 1996). Except for few genetically mutant individuals, leptin treatment always induces the development of leptin resistance in both diet-induced rodent models of obesity or obese human (Banks et al. 2004, Ozcan et al. 2009), the cause of this kind of resistance to leptin has yet to be explained.

With regards to the leptin resistance, age, sex and season are other major factors affecting leptin sensitivity. Aged rats demonstrate a reduced responsiveness to peripheral and central leptin, and the mechanism may involve impaired suppression of hypothalamic NPY mRNA that may be a consequence of impaired leptin signal transduction (Scarpace et al. 2001). An overexpressing leptin transgenic mice model experiment demonstrated a two-stage phenotype with 
respect to fat accumulation (Qiu et al. 2001). At 6-9 weeks of age, the transgenic mice responded to the moderate hyperleptinemia and reduced the brown and white fat depots, whereas the transgenic mice showed a rebound effect characterized by an increase in body weight and accumulation of adipose mass at 33-37 weeks (Qiu et al. 2001). Similarly, in the female rats, GnRH pulse amplitude was significantly increased by leptin treatment while no such effects were seen in the male (Parent et al. 2000). In Romney Marsh sheep, centrally injected leptin had no significant effect on the voluntary food intake in both sexes during autumn. In spring, however, leptin exhibited a profound inhibitory effect on food intake in females, but only a slight effect in males (Clarke et al. 2001). These data indicate that responsiveness to leptin depends on sex and also on season in animals whose food intakes are substantially affected by photoperiod (Clarke et al. 2001).

The availability of a murine model with chronically raised leptin levels has also provided new insights into the role played by leptin in reproduction. With no apparent adipose tissue and high leptin concentrations, the female transgenic skinny mice exhibit accelerated puberty and intact fertility at younger ages, followed by late-onset hypothalamic hypogonadism that is characterized by prolonged estrus, atrophic ovaries and reduced gonadotropin-releasing hormone $(\mathrm{GnRH})$ and LH secretion (Yura et al. 2000). Hyperleptinemia in vivo seems to facilitate the onset of puberty but, if chronically persistent, it can later downregulate the central leptin signals that stimulate reproductive function, or interfere with gonadotropin stimulation of peripheral targets (Yura et al. 2000).

The potential mechanism for leptin resistance has yet to be fully defined. A new concept of selective leptin resistance has been raised recently based on the studies in agouti yellow obese $(A y)$ mice (Correia et al. 2002). The agouti mice are obese and resistant to the satiety and weight reducing actions of leptin (Halaas and Friedman 1997), even though they do not have mutations in the leptin receptor gene (Correia et al. 2002). Leptininduced decreases in food intake and body weight were less in agouti obese mice than in lean littermates. In contrast, leptin-induced increases in sympathetic nerve activity did not differ in obese and lean mice. These findings led to the concept of selective leptin resistance, with resistance to the metabolic actions of leptin but preservation of the sympathoexcitatory actions (Correia et al. 2002). This finding may have potential implications for human obesity, which is associated with elevated plasma leptin and is thought to be a leptin-resistant state. If leptin resistance is selective in obese humans, then leptin could contribute to sympathetic overactivity and its adverse consequences in human obesity (Correia et al. 2002).

In addition, suppressor of cytokine signaling 3 (SOCS3) (Banks et al. 2004, Bjorbak et al. 2000), tyrosine phosphatase 1 B (PTB1B) (Bence et al. 2006) and serine phosphorylation of Janus kinase 2 (Jak2) have been demonstrated to have important roles in the blockade of leptin signaling (Ishida-Takahashi et al. 2006). A recently studied showed that increased endoplasmic reticulum stress and activation of the unfolded protein response in the hypothalamus of obsess mice inhibit leptin receptor signaling (Ozcan et al. 2009). It would be interesting to understand that if leptin resistance during pregnancy is also mediated through the above mentioned pathways since the situation usually be reverted back to normal after parturition. However, we don't think this will be a case from an evolutionary point of view because a normal physiological process won't employ such a stressed-related mechanism to modulate its signaling.

\section{Implications for human reproduction}

For humans, the combination of advanced reproductive female age (Marino et al. 2011, Navot et al. 1991) and maternal obesity (Dokras et al. 2006, Fedorcsak et al. 2004, Zander-Fox et al. 2012) has led to a rapid increase in the demand for assisted reproductive technology (ART), with a consequent cost to the healthcare system. Poor ovarian response to controlled ovarian hyperstimulation $(\mathrm{COH})$ and deterioration of oocyte quality are two major causes for obese and/or agerelated decline of fertility (Fedorcsak et al. 2004). However, there is currently no clinically effective method to improve the fertility in these patients. The coadministration of anti-leptin during the conventional $\mathrm{COH}$ may increase the sensitivity of ovaries to gonadotrophins (Panwar et al. 2012) and lead to an efficient, safe and reliable approach to assisting these special patients to become pregnant.

\section{Conclusions}

In addition to the recognition of the importance of leptin in restoration of fertility in $o b / o b$ mice, several 
lines of evidences, e.g. 1) the correlation of lower follicular fluid leptin concentration and success of IVF treatment in normal woman (Mantzoros et al. 2000), 2) the importance of low leptin for the normal adaptive response of the placenta to reduced energy viability (Schulz et al. 2012), 3) the reduction of leptin in the circulation promotes ovarian follicle development in female mice (Panwar et al. 2012), indicate that relatively higher leptin level in the circulation may be a possible mechanism for controlling ovulation rate, implantation number and litter size in multi-litter species in normal physiological conditions.

The majority of the studies that investigated the role of leptin in reproduction of normal animals have used supra-physiological leptin concentrations (Craig et al. 2005, Herrid et al. 2008b, Kawamura et al. 2002), this may have resulted in conflicting results and jeopardized our ability to determine the role of leptin on these biological processes since leptin has been shown to exert biophysical effects on different type of cells/organs (Herrid et al. 2006, Yu et al. 1997b) or this might have led to a leptin resistance status caused by endoplasmic reticular stress (Ozcan et al. 2009). Therefore it is important to realize this feature of leptin in designing biological experiments to investigate its functions. Our approaches to use anti-leptin antibodies or other antagonists (Gertler and Elinav 2014) to neutralize peripheral leptin levels in experimental animals might be a novel way to overcome this problem as we demonstrated recently (Panwar et al. 2012).

\section{Conflict of Interest}

There is no conflict of interest.

\section{References}

ALFER J, MULLER-SCHOTTLE F, CLASSEN-LINKE I, VON RANGO U, HAPPEL L, BEIER-HELLWIG K, RATH W, BEIER HM: The endometrium as a novel target for leptin: differences in fertility and subfertility. Mol Hum Reprod 6: 595-601, 2000.

ALMOG B, GOLD R, TAJIMA K, DANTES A, SALIM K, RUBINSTEIN M, BARKAN D, HOMBURG R, LESSING JB, NEVO N, GERTLER A, AMSTERDAM A: Leptin attenuates follicular apoptosis and accelerates the onset of puberty in immature rats. Mol Cell Endocrinol 183: 179-191, 2001.

AMLEH A, DEAN J: Mouse genetics provides insight into folliculogenesis, fertilization and early embryonic development. Hum Reprod Update 8: 395-403, 2002.

ANTCZAK M, VAN BLERKOM J, CLARK A: A novel mechanism of vascular endothelial growth factor, leptin and transforming growth factor-beta2 sequestration in a subpopulation of human ovarian follicle cells. Hum Reprod 12: 2226-2234, 1997.

ARCH JR, STOCK MJ, TRAYHURN P: Leptin resistance in obese humans: does it exist and what does it mean? Int $J$ Obes Relat Metab Disord 22: 1159-1163, 1998.

ASHWORTH CJ, HOGGARD N, THOMAS L, MERCER JG, WALLACE JM, LEA RG: Placental leptin. Rev Reprod 5: $18-24,2000$.

BACART J, LELOIRE A, LEVOYE A, FROGUEL P, JOCKERS R, COUTURIER C: Evidence for leptin receptor isoforms heteromerization at the cell surface. FEBS Lett 584: 2213-2217, 2010.

BANKS WA, COON AB, ROBINSON SM, MOINUDDIN A, SHULTZ JM, NAKAOKE R, MORLEY JE: Triglycerides induce leptin resistance at the blood-brain barrier. Diabetes 53: 1253-1260, 2004.

BARASH IA, CHEUNG CC, WEIGLE DS, REN H, KABIGTING EB, KUIJPER JL, CLIFTON DK, STEINER RA: Leptin is a metabolic signal to the reproductive system. Endocrinology 137: 3144-3147, 1996.

BARROSO G, BARRIONUEVO M, RAO P, GRAHAM L, DANFORTH D, HUEY S, ABUHAMAD A, OEHNINGER S: Vascular endothelial growth factor, nitric oxide, and leptin follicular fluid levels correlate negatively with embryo quality in IVF patients. Fertil Steril 72: 1024-1026, 1999.

BENCE KK, DELIBEGOVIC M, XUE B, GORGUN CZ, HOTAMISLIGIL GS, NEEL BG, KAHN BB: Neuronal PTP1B regulates body weight, adiposity and leptin action. Nat Med 12: 917-924, 2006.

BJORBAK C, LAVERY HJ, BATES SH, OLSON RK, DAVIS SM, FLIER JS, MYERS MG Jr: SOCS3 mediates feedback inhibition of the leptin receptor via Tyr985. J Biol Chem 275: 40649-40657, 2000. 
BRANNIAN JD, SCHMIDT SM, KREGER DO, HANSEN KA: Baseline non-fasting serum leptin concentration to body mass index ratio is predictive of IVF outcomes. Hum Reprod 16: 1819-1826, 2001.

BUTZOW TL, MOILANEN JM, LEHTOVIRTA M, TUOMI T, HOVATTA O, SIEGBERG R, NILSSON CG, APTER D: Serum and follicular fluid leptin during in vitro fertilization: relationship among leptin increase, body fat mass, and reduced ovarian response. J Clin Endocrinol Metab 84: 3135-3139, 1999.

CAMPFIELD LA, SMITH FJ: Overview: neurobiology of OB protein (leptin). Proc Nutr Soc 57: 429-440, 1998.

CARO JF, SINHA MK, KOLACZYNSKI JW, ZHANG PL, CONSIDINE RV: Leptin: the tale of an obesity gene. Diabetes 45: 1455-1462, 1996.

CELLA F, GIORDANO G, CORDERA R: Serum leptin concentrations during the menstrual cycle in normal-weight women: effects of an oral triphasic estrogen-progestin medication. Eur J Endocrinol 142: 174-178, 2000.

CHEHAB FF: A broader role for leptin. Nat Med 2: 723-724, 1996.

CHEHAB FF, LIM ME, LU R: Correction of the sterility defect in homozygous obese female mice by treatment with the human recombinant leptin. Nat Genet 12: 318-320, 1996.

CHIEN EK, HARA M, ROUARD M, YANO H, PHILLIPPE M, POLONSKY KS, BELL GI: Increase in serum leptin and uterine leptin receptor messenger RNA levels during pregnancy in rats. Biochem Biophys Res Commun 237: 476-480, 1997.

CIOFFI JA, VAN BLERKOM J, ANTCZAK M, SHAFER A, WITTMER S, SNODGRASS HR: The expression of leptin and its receptors in pre-ovulatory human follicles. Mol Hum Reprod 3: 467-472, 1997.

CLARKE IJ, HENRY B, IQBAL J, GODING JW: Leptin and the regulation of food intake and the neuroendocrine axis in sheep. Clin Exp Pharmacol Physiol 28: 106-107, 2001.

CORREIA ML, HAYNES WG, RAHMOUNI K, MORGAN DA, SIVITZ WI, MARK AL: The concept of selective leptin resistance: evidence from agouti yellow obese mice. Diabetes 51: 439-442, 2002.

CRAIG JA, ZHU H, DYCE PW, WEN L, LI J: Leptin enhances porcine preimplantation embryo development in vitro. Mol Cell Endocrinol 229: 141-147, 2005.

CUNNINGHAM MJ, CLIFTON DK, STEINER RA: Leptin's actions on the reproductive axis: perspectives and mechanisms. Biol Reprod 60: 216-222, 1999.

DOKRAS A, BAREDZIAK L, BLAINE J, SYROP C, VANVOORHIS BJ, SPARKS A: Obstetric outcomes after in vitro fertilization in obese and morbidly obese women. Obstet Gynecol 108: 61-69, 2006.

DOTSCH J, NUSKEN KD, KNERR I, KIRSCHBAUM M, REPP R, RASCHER W: Leptin and neuropeptide Y gene expression in human placenta: ontogeny and evidence for similarities to hypothalamic regulation. $J$ Clin Endocrinol Metab 84: 2755-2758, 1999.

DYER CJ, SIMMONS JM, MATTERI RL, KEISLER DH: Effects of an intravenous injection of NPY on leptin and NPY-Y1 receptor mRNA expression in ovine adipose tissue. Domest Anim Endocrinol 14: 325-333, 1997a.

DYER CJ, SIMMONS JM, MATTERI RL, KEISLER DH: Leptin receptor mRNA is expressed in ewe anterior pituitary and adipose tissues and is differentially expressed in hypothalamic regions of well-fed and feedrestricted ewes. Domest Anim Endocrinol 14: 119-128, $1997 \mathrm{~b}$.

ELIAS CF, ASCHKENASI C, LEE C, KELLY J, AHIMA RS, BJORBAEK C, FLIER JS, SAPER CB, ELMQUIST JK: Leptin differentially regulates NPY and POMC neurons projecting to the lateral hypothalamic area. Neuron 23: 775-786, 1999.

ERICKSON JC, CLEGG KE, PALMITER RD: Sensitivity to leptin and susceptibility to seizures of mice lacking neuropeptide Y. Nature 381: 415-421, 1996.

FEDORCSAK P, DALE PO, STORENG R, ERTZEID G, BJERCKE S, OLDEREID N, OMLAND AK, ABYHOLM $\mathrm{T}$, TANBO T: Impact of overweight and underweight on assisted reproduction treatment. Hum Reprod 19: 2523-2528, 2004.

FEI H, OKANO HJ, LI C, LEE GH, ZHAO C, DARNELL R, FRIEDMAN JM: Anatomic localization of alternatively spliced leptin receptors (Ob-R) in mouse brain and other tissues. Proc Natl Acad Sci USA 94: 7001-7005, 1997.

FINN PD, CUNNINGHAM MJ, PAU KY, SPIES HG, CLIFTON DK, STEINER RA: The stimulatory effect of leptin on the neuroendocrine reproductive axis of the monkey. Endocrinology 139: 4652-4662, 1998.

FRUHBECK G: Intracellular signalling pathways activated by leptin. Biochem J 393: 7-20, 2006. 
FUNAHASHI H, RYUSHI T, MIZUSHIMA H, KATOH S, SHIODA S: Ultrastructural localization of the receptor for leptin in the rat hypothalamus. Horm Behav 37: 327-334, 2000.

FUNGFUANG W, NAKADA T, NAKAO N, TERADA M, YOKOSUKA M, GIZURARSON S, HAU J, MOON C, SAITO TR: Serum leptin concentrations, leptin mRNA expression, and food intake during the estrous cycle in rats. Lab Anim Res 29: 1-6, 2013.

GARCIA MD, CASANUEVA FF, DIEGUEZ C, SENARIS RM: Gestational profile of leptin messenger ribonucleic acid (mRNA) content in the placenta and adipose tissue in the rat, and regulation of the mRNA levels of the leptin receptor subtypes in the hypothalamus during pregnancy and lactation. Biol Reprod 62: 698-703, 2000.

GAVRILOVA O, BARR V, MARCUS-SAMUELS B, REITMAN M: Hyperleptinemia of pregnancy associated with the appearance of a circulating form of the leptin receptor. J Biol Chem 272: 30546-30551, 1997.

GERTLER A, ELINAV E: Novel superactive leptin antagonists and their potential therapeutic applications. Curr Pharm Des 20: 659-665, 2014.

GONZALEZ LC, PINILLA L, TENA-SEMPERE M, DIEGUEZ C, CASANUEVA FF, AGUILAR E: Effect of acute immunoneutralization of endogenous leptin on prolactin and LH secretion during the afternoon of pro-oestrus or in steroid-treated ovariectomized female rats. J Reprod Fertil 118: 39-45, 2000.

GONZALEZ RR, CABALLERO-CAMPO P, JASPER M, MERCADER A, DEVOTO L, PELLICER A, SIMON C: Leptin and leptin receptor are expressed in the human endometrium and endometrial leptin secretion is regulated by the human blastocyst. J Clin Endocrinol Metab 85: 4883-4888, 2000.

HAKANSSON ML, HULTING AL, MEISTER B: Expression of leptin receptor mRNA in the hypothalamic arcuate nucleus--relationship with NPY neurones. Neuroreport 7: 3087-3092, 1996.

HAKANSSON ML, MEISTER B: Transcription factor STAT3 in leptin target neurons of the rat hypothalamus. Neuroendocrinology 68: 420-427, 1998.

HALAAS JL, FRIEDMAN JM: Leptin and its receptor. J Endocrinol 155: 215-216, 1997.

HARDIE L, TRAYHURN P, ABRAMOVICH D, FOWLER P: Circulating leptin in women: a longitudinal study in the menstrual cycle and during pregnancy. Clin Endocrinol (Oxf) 47: 101-106, 1997.

HASSINK SG, DE LANCEY E, SHESLOW DV, SMITH-KIRWIN SM, O'CONNOR DM, CONSIDINE RV, OPENTANOVA I, DOSTAL K, SPEAR ML, LEEF K, ASH M, SPITZER AR, FUNANAGE VL: Placental leptin: an important new growth factor in intrauterine and neonatal development? Pediatrics 100: e1, 1997.

HAUSMAN GJ, BARB CR, LENTS CA: Leptin and reproductive function. Biochimie 94: 2075-2081, 2012.

HENSON MC, CASTRACANE VD: Leptin in pregnancy. Biol Reprod 63: 1219-1228, 2000.

HERRID M, NGUYEN VL, HINCH G, MCFARLANE JR: Leptin has concentration and stage-dependent effects on embryonic development in vitro. Reproduction 132: 247-256, 2006.

HERRID M, O'SHEA T, MCFARLANE JR: Ontogeny of leptin and its receptor expression in mouse testis during the postnatal period. Mol Reprod Dev 75: 874-880, 2008a.

HERRID M, XIA Y, O'SHEA T, MCFARLANE JR: Leptin inhibits basal but not gonadotrophin-stimulated testosterone production in the immature mouse and sheep testis. Reprod Fertil Dev 20: 519-528, $2008 \mathrm{~b}$.

HOGGARD N, HUNTER L, DUNCAN JS, WILLIAMS LM, TRAYHURN P, MERCER JG: Leptin and leptin receptor mRNA and protein expression in the murine fetus and placenta. Proc Natl Acad Sci USA 94: 1107311078, 1997.

HOGGARD N, HAGGARTY P, THOMAS L, LEA RG: Leptin expression in placental and fetal tissues: does leptin have a functional role? Biochem Soc Trans 29: 57-63, 2001.

HOLNESS MJ, MUNNS MJ, SUGDEN MC: Current concepts concerning the role of leptin in reproductive function. Mol Cell Endocrinol 157: 11-20, 1999.

HOUSEKNECHT KL, BAILE CA, MATTERI RL, SPURLOCK ME: The biology of leptin: a review. J Anim Sci 76: 1405-1420, 1998.

INGALLS AM, DICKIE MM, SNELL GD: Obese, a new mutation in the house mouse. $J$ Hered 41: 317-318, 1950.

IQBAL J, POMPOLO S, MURAKAMI T, GROUZMANN E, SAKURAI T, MEISTER B, CLARKE IJ: Immunohistochemical characterization of localization of long-form leptin receptor (OB-Rb) in neurochemically defined cells in the ovine hypothalamus. Brain Res 920: 55-64, 2001. 
ISHIDA-TAKAHASHI R, ROSARIO F, GONG Y, KOPP K, STANCHEVA Z, CHEN X, FEENER EP, MYERS MG Jr: Phosphorylation of Jak2 on Ser(523) inhibits Jak2-dependent leptin receptor signaling. Mol Cell Biol 26: 4063-4073, 2006.

JIN L, BURGUERA BG, COUCE ME, SCHEITHAUER BW, LAMSAN J, EBERHARDT NL, KULIG E, LLOYD $\mathrm{RV}$ : Leptin and leptin receptor expression in normal and neoplastic human pituitary: evidence of a regulatory role for leptin on pituitary cell proliferation. J Clin Endocrinol Metab 84: 2903-2911, 1999.

JIN L, ZHANG S, BURGUERA BG, COUCE ME, OSAMURA RY, KULIG E, LLOYD RV: Leptin and leptin receptor expression in rat and mouse pituitary cells. Endocrinology 141: 333-339, 2000.

KARLSSON C, LINDELL K, SVENSSON E, BERGH C, LIND P, BILLIG H, CARLSSON LM, CARLSSON B: Expression of functional leptin receptors in the human ovary. J Clin Endocrinol Metab 82: 4144-4148, 1997.

KAWAMURA K, SATO N, FUKUDA J, KODAMA H, KUMAGAI J, TANIKAWA H, NAKAMURA A, TANAKA T: Leptin promotes the development of mouse preimplantation embryos in vitro. Endocrinology 143: 19221931, 2002.

KAWAMURA K, SATO N, FUKUDA J, KODAMA H, KUMAGAI J, TANIKAWA H, MURATA M, TANAKA T: The role of leptin during the development of mouse preimplantation embryos. Mol Cell Endocrinol 202: 185189, 2003.

KENDALL NR, GUTIERREZ CG, SCARAMUZZI RJ, BAIRD DT, WEBB R, CAMPBELL BK: Direct in vivo effects of leptin on ovarian steroidogenesis in sheep. Reproduction 128: 757-765, 2004.

KHAN SM, HAMNVIK OP, BRINKOETTER M, MANTZOROS CS: Leptin as a modulator of neuroendocrine function in humans. Yonsei Med J 53: 671-679, 2012.

KIKUCHI N, ANDOH K, ABE Y, YAMADA K, MIZUNUMA H, IBUKI Y: Inhibitory action of leptin on early follicular growth differs in immature and adult female mice. Biol Reprod 65: 66-71, 2001.

KIM HS, LEE GS, KIM JH, KANG SK, LEE BC, HWANG WS: Expression of leptin ligand and receptor and effect of exogenous leptin supplement on in vitro development of porcine embryos. Theriogenology 65: 831-844, 2006.

KINEMAN RD, LESHIN LS, CRIM JW, RAMPACEK GB, KRAELING RR: Localization of luteinizing hormonereleasing hormone in the forebrain of the pig. Biol Reprod 39: 665-672, 1988.

KINEMAN RD, KRAELING RR, CRIM JW, LESHIN LS, BARB CR, RAMPACEK GB: Localization of proopiomelanocortin (POMC) immunoreactive neurons in the forebrain of the pig. Biol Reprod 40: 1119-1126, 1989.

KITAWAKI J, KOSHIBA H, ISHIHARA H, KUSUKI I, TSUKAMOTO K, HONJO H: Expression of leptin receptor in human endometrium and fluctuation during the menstrual cycle. J Clin Endocrinol Metab 85: 1946-1950, 2000.

KOSHIBA H, KITAWAKI J, ISHIHARA H, KADO N, KUSUKI I, TSUKAMOTO K, HONJO H: Progesterone inhibition of functional leptin receptor mRNA expression in human endometrium. Mol Hum Reprod 7: 567$572,2001$.

LAIRD SM, QUINTON ND, ANSTIE B, LI TC, BLAKEMORE AI: Leptin and leptin-binding activity in women with recurrent miscarriage: correlation with pregnancy outcome. Hum Reprod 16: 2008-2013, 2001.

LEBRETHON MC, VANDERSMISSEN E, GERARD A, PARENT AS, JUNIEN JL, BOURGUIGNON JP: In vitro stimulation of the prepubertal rat gonadotropin-releasing hormone pulse generator by leptin and neuropeptide Y through distinct mechanisms. Endocrinology 141: 1464-1469, 2000.

LESHIN LS, KRAELING RR, KISER TE: Immunocytochemical localization of the catecholamine-synthesizing enzymes, tyrosine hydroxylase and dopamine-beta-hydroxylase, in the hypothalamus of cattle. $J$ Chem Neuroanat 9: 175-194, 1995.

LEWANDOWSKI K, HORN R, O'CALLAGHAN CJ, DUNLOP D, MEDLEY GF, O'HARE P, BRABANT G: Free leptin, bound leptin, and soluble leptin receptor in normal and diabetic pregnancies. $J$ Clin Endocrinol Metab 84: 300-306, 1999.

LI Z, CECCARINI G, EISENSTEIN M, TAN K, FRIEDMAN JM: Phenotypic effects of an induced mutation of the ObRa isoform of the leptin receptor. Mol Metab 2: 364-375, 2013.

LIN J, RICHARD BARB C, KRAELING RR, RAMPACEK GB: Developmental changes in the long form leptin receptor and related neuropeptide gene expression in the pig brain. Biol Reprod 64: 1614-1618, 2001. 
LIU C, LIU XJ, BARRY G, LING N, MAKI RA, DE SOUZA EB: Expression and characterization of a putative high affinity human soluble leptin receptor. Endocrinology 138: 3548-3554, 1997.

LOU PH, YANG G, HUANG L, CUI Y, POURBAHRAMI T, RADDA GK, LI C, HAN W: Reduced body weight and increased energy expenditure in transgenic mice over-expressing soluble leptin receptor. PLoS One 5: e11669, 2010.

MAGKOS F, BRENNAN A, SWEENEY L, KANG ES, DOWEIKO J, KARCHMER AW, MANTZOROS CS: Leptin replacement improves postprandial glycemia and insulin sensitivity in human immunodeficiency virus-infected lipoatrophic men treated with pioglitazone: a pilot study. Metabolism 60: 1045-1049, 2011.

MALIK NM, CARTER ND, MURRAY JF, SCARAMUZZI RJ, WILSON CA, STOCK MJ: Leptin requirement for conception, implantation, and gestation in the mouse. Endocrinology 142: 5198-5202, 2001.

MANTZOROS CS: Role of leptin in reproduction. Ann N Y Acad Sci 900: 174-183, 2000.

MANTZOROS CS, CRAMER DW, LIBERMAN RF, BARBIERI RL: Predictive value of serum and follicular fluid leptin concentrations during assisted reproductive cycles in normal women and in women with the polycystic ovarian syndrome. Hum Reprod 15: 539-544, 2000.

MANTZOROS CS, MAGKOS F, BRINKOETTER M, SIENKIEWICZ E, DARDENO TA, KIM SY, HAMNVIK OP, KONIARIS A: Leptin in human physiology and pathophysiology. Am J Physiol 301: E567-E584, 2011.

MARINO JL, MOORE VM, RUMBOLD AR, DAVIES MJ: Fertility treatments and the young women who use them: an Australian cohort study. Hum Reprod 26: 473-479, 2011.

MASUZAKI H, OGAWA Y, SAGAWA N, HOSODA K, MATSUMOTO T, MISE H, NISHIMURA H, YOSHIMASA Y, TANAKA I, MORI T, NAKAO K: Nonadipose tissue production of leptin: leptin as a novel placenta-derived hormone in humans. Nat Med 3: 1029-1033, 1997.

MERCER JG, HOGGARD N, WILLIAMS LM, LAWRENCE CB, HANNAH LT, MORGAN PJ, TRAYHURN P: Coexpression of leptin receptor and preproneuropeptide Y mRNA in arcuate nucleus of mouse hypothalamus. J Neuroendocrinol 8: 733-735, 1996a.

MERCER JG, HOGGARD N, WILLIAMS LM, LAWRENCE CB, HANNAH LT, TRAYHURN P: Localization of leptin receptor mRNA and the long form splice variant $(\mathrm{Ob}-\mathrm{Rb})$ in mouse hypothalamus and adjacent brain regions by in situ hybridization. FEBS Lett 387: 113-116, 1996b.

MISTRY AM, SWICK A, ROMSOS DR: Leptin alters metabolic rates before acquisition of its anorectic effect in developing neonatal mice. Am J Physiol 277: R742-R747, 1999.

MONTAGUE CT, FAROOQI IS, WHITEHEAD JP, SOOS MA, RAU H, WAREHAM NJ, SEWTER CP, DIGBY JE, MOHAMMED SN, HURST JA, CHEETHAM CH, EARLEY AR, BARNETT AH, PRINS JB, O'RAHILLY S: Congenital leptin deficiency is associated with severe early-onset obesity in humans. Nature 387: 903-908, 1997.

MORASH B, LI A, MURPHY PR, WILKINSON M, UR E: Leptin gene expression in the brain and pituitary gland. Endocrinology 140: 5995-5998, 1999.

MORASH BA, IMRAN A, WILKINSON D, UR E, WILKINSON M: Leptin receptors are developmentally regulated in rat pituitary and hypothalamus. Mol Cell Endocrinol 210: 1-8, 2003.

MOUNZIH K, LU R, CHEHAB FF: Leptin treatment rescues the sterility of genetically obese ob/ob males. Endocrinology 138: 1190-1193, 1997.

NAVOT D, BERGH PA, WILLIAMS MA, GARRISI GJ, GUZMAN I, SANDLER B, GRUNFELD L: Poor oocyte quality rather than implantation failure as a cause of age-related decline in female fertility. Lancet 337: 13751377, 1991.

OHTAKE M, BRAY GA, AZUKIZAWA M: Studies on hypothermia and thyroid function in the obese (ob/ob) mouse. Am J Physiol 233: R110-R115, 1977.

OZCAN L, ERGIN AS, LU A, CHUNG J, SARKAR S, NIE D, MYERS MG Jr, OZCAN U: Endoplasmic reticulum stress plays a central role in development of leptin resistance. Cell Metab 9: 35-51, 2009.

PANWAR S, HERRID M, KAUTER KG, MCFARLANE JR: Effect of passive immunization against leptin on ovarian follicular development in prepubertal mice. J Reprod Immunol 96: 19-24, 2012. 
PARENT AS, LEBRETHON MC, GERARD A, VANDERSMISSEN E, BOURGUIGNON JP: Leptin effects on pulsatile gonadotropin releasing hormone secretion from the adult rat hypothalamus and interaction with cocaine and amphetamine regulated transcript peptide and neuropeptide Y. Regul Pept 92: 17-24, 2000.

PATEL N, BRINKMAN-VAN DER LINDEN EC, ALTMANN SW, GISH K, BALASUBRAMANIAN S, TIMANS JC, PETERSON D, BELL MP, BAZAN JF, VARKI A, KASTELEIN RA: OB-BP1/Siglec-6. A leptin- and sialic acid-binding protein of the immunoglobulin superfamily. J Biol Chem 274: 22729-22738, 1999.

QIU J, OGUS S, LU R, CHEHAB FF: Transgenic mice overexpressing leptin accumulate adipose mass at an older, but not younger, age. Endocrinology 142: 348-358, 2001.

QUENNELL JH, MULLIGAN AC, TUPS A, LIU X, PHIPPS SJ, KEMP CJ, HERBISON AE, GRATTAN DR, ANDERSON GM: Leptin indirectly regulates gonadotropin-releasing hormone neuronal function. Endocrinology 150: 2805-2812, 2009.

QUINTON ND, LAIRD SM, OKON MA, LI TC, SMITH RF, ROSS RJ, BLAKEMORE AI: Serum leptin levels during the menstrual cycle of healthy fertile women. Br J Biomed Sci 56: 16-19, 1999.

RAMOS MP, RUEDA BR, LEAVIS PC, GONZALEZ RR: Leptin serves as an upstream activator of an obligatory signaling cascade in the embryo-implantation process. Endocrinology 146: 694-701, 2005.

RUIZ-CORTES ZT, MEN T, PALIN MF, DOWNEY BR, LACROIX DA, MURPHY BD: Porcine leptin receptor: molecular structure and expression in the ovary. Mol Reprod Dev 56: 465-474, 2000.

RYAN NK, WOODHOUSE CM, VAN DER HOEK KH, GILCHRIST RB, ARMSTRONG DT, NORMAN RJ: Expression of leptin and its receptor in the murine ovary: possible role in the regulation of oocyte maturation. Biol Reprod 66: 1548-1554, 2002.

SCARPACE PJ, MATHENY M, TUMER N: Hypothalamic leptin resistance is associated with impaired leptin signal transduction in aged obese rats. Neuroscience 104: 1111-1117, 2001.

SCHULZ LC, ROBERTS RM: Dynamic changes in leptin distribution in the progression from ovum to blastocyst of the pre-implantation mouse embryo. Reproduction 141: 767-777, 2011.

SCHULZ LC, WIDMAIER EP, QIU J, ROBERTS RM: Effect of leptin on mouse trophoblast giant cells. Biol Reprod 80: 415-424, 2009.

SCHULZ LC, SCHLITT JM, CAESAR G, PENNINGTON KA: Leptin and the placental response to maternal food restriction during early pregnancy in mice. Biol Reprod 87: 120, 2012.

SCHWARTZ MW, BASKIN DG, BUKOWSKI TR, KUIJPER JL, FOSTER D, LASSER G, PRUNKARD DE, PORTE D, JR., WOODS SC, SEELEY RJ, WEIGLE DS: Specificity of leptin action on elevated blood glucose levels and hypothalamic neuropeptide Y gene expression in ob/ob mice. Diabetes 45: 531-535, 1996.

SCHWARTZ MW, ERICKSON JC, BASKIN DG, PALMITER RD: Effect of fasting and leptin deficiency on hypothalamic neuropeptide $\mathrm{Y}$ gene transcription in vivo revealed by expression of a lacZ reporter gene. Endocrinology 139: 2629-2635, 1998.

SHIMON I, YAN X, MAGOFFIN DA, FRIEDMAN TC, MELMED S: Intact leptin receptor is selectively expressed in human fetal pituitary and pituitary adenomas and signals human fetal pituitary growth hormone secretion. J Clin Endocrinol Metab 83: 4059-4064, 1998.

SIVAN E, WHITTAKER PG, SINHA D, HOMKO CJ, LIN M, REECE EA, BODEN G: Leptin in human pregnancy: the relationship with gestational hormones. Am J Obstet Gynecol 179: 1128-1132, 1998.

SPICER LJ, FRANCISCO CC: The adipose obese gene product, leptin: evidence of a direct inhibitory role in ovarian function. Endocrinology 138: 3374-3379, 1997.

SPICER LJ, CHAMBERLAIN CS, FRANCISCO CC: Ovarian action of leptin: effects on insulin-like growth factor-Istimulated function of granulosa and thecal cells. Endocrine 12: 53-59, 2000.

TARTAGLIA LA, DEMBSKI M, WENG X, DENG N, CULPEPPER J, DEVOS R, RICHARDS GJ, CAMPFIELD LA, CLARK FT, DEEDS J, MUIR C, SANKER S, MORIARTY A, MOORE KJ, SMUTKO JS, MAYS GG, WOOL EA, MONROE CA, TEPPER RI: Identification and expression cloning of a leptin receptor, OB-R. Cell 83: 1263-1271, 1995.

TERADA Y, YAMAKAWA K, SUGAYA A, TOYODA N: Serum leptin levels do not rise during pregnancy in agematched rats. Biochem Biophys Res Commun 253: 841-844, 1998. 
THOMAS L, WALLACE JM, AITKEN RP, MERCER JG, TRAYHURN P, HOGGARD N: Circulating leptin during ovine pregnancy in relation to maternal nutrition, body composition and pregnancy outcome. $J$ Endocrinol 169: 465-476, 2001.

THORNTON JE, CHEUNG CC, CLIFTON DK, STEINER RA: Regulation of hypothalamic proopiomelanocortin mRNA by leptin in ob/ob mice. Endocrinology 138: 5063-5066, 1997.

TOMIMATSU T, YAMAGUCHI M, MURAKAMI T, OGURA K, SAKATA M, MITSUDA N, KANZAKI T, KURACHI H, IRAHARA M, MIYAKE A, SHIMA K, AONO T, MURATA Y: Increase of mouse leptin production by adipose tissue after midpregnancy: gestational profile of serum leptin concentration. Biochem Biophys Res Commun 240: 213-215, 1997.

TRITOS NA, MANTZOROS CS: Leptin: its role in obesity and beyond. Diabetologia 40: 1371-1379, 1997.

TUNGTRONGCHITR R, PONGPAEW P, PHONRAT B, TRIBUNYATKUL S, VIROONUDOMPHOL D, SUPAWAN V, JINTARIDHI P, LERTCHAVANAKUL A, VUDHIVAI N, SCHELP FP: Leptin concentration in relation to body mass index (BMI) and hematological measurements in Thai obese and overweight subjects. Southeast Asian J Trop Med Public Health 31: 787-794, 2000.

UNKILA-KALLIO L, ANDERSSON S, KOISTINEN HA, KARONEN SL, YLIKORKALA O, TIITINEN A: Leptin during assisted reproductive cycles: the effect of ovarian stimulation and of very early pregnancy. Hum Reprod 16: 657-662, 2001.

WHITE DW, TARTAGLIA LA: Evidence for ligand-independent homo-oligomerization of leptin receptor (OB-R) isoforms: a proposed mechanism permitting productive long-form signaling in the presence of excess shortform expression. J Cell Biochem 73: 278-288, 1999.

WHITE DW, ZHOU J, STRICKER-KRONGRAD A, GE P, MORGENSTERN JP, DEMBSKI M, TARTAGLIA LA: Identification of leptin-induced transcripts in the mouse hypothalamus. Diabetes 49: 1443-1450, 2000.

YU WH, KIMURA M, WALCZEWSKA A, KARANTH S, MCCANN SM: Role of leptin in hypothalamic-pituitary function. Proc Natl Acad Sci USA 94: 1023-1028, 1997a.

YU WH, WALCZEWSKA A, KARANTH S, MCCANN SM: Nitric oxide mediates leptin-induced luteinizing hormone-releasing hormone (LHRH) and LHRH and leptin-induced LH release from the pituitary gland. Endocrinology 138: 5055-5058, $1997 \mathrm{~b}$.

YURA S, OGAWA Y, SAGAWA N, MASUZAKI H, ITOH H, EBIHARA K, AIZAWA-ABE M, FUJII S, NAKAO $\mathrm{K}$ : Accelerated puberty and late-onset hypothalamic hypogonadism in female transgenic skinny mice overexpressing leptin. J Clin Invest 105: 749-755, 2000.

ZACHOW RJ, MAGOFFIN DA: Direct intraovarian effects of leptin: impairment of the synergistic action of insulinlike growth factor-I on follicle-stimulating hormone-dependent estradiol-17 beta production by rat ovarian granulosa cells. Endocrinology 138: 847-850, 1997.

ZACHOW RJ, WEITSMAN SR, MAGOFFIN DA: Leptin impairs the synergistic stimulation by transforming growth factor-beta of follicle-stimulating hormone-dependent aromatase activity and messenger ribonucleic acid expression in rat ovarian granulosa cells. Biol Reprod 61: 1104-1109, 1999.

ZAMORANO PL, DE SEVILLA L, MAHESH VB, BRANN DW: Production and refolding of recombinant leptin. Biotechniques 23: 800-802, 804, 1997.

ZANDER-FOX DL, HENSHAW R, HAMILTON H, LANE M: Does obesity really matter? The impact of BMI on embryo quality and pregnancy outcomes after IVF in women aged $\leq 38$ years. Aust N Z J Obstet Gynaecol 52: 270-276, 2012.

ZHANG Y, PROENCA R, MAFFEI M, BARONE M, LEOPOLD L, FRIEDMAN JM: Positional cloning of the mouse obese gene and its human homologue. Nature 372: 425-432, 1994.

ZHAO Y, KREGER DO, BRANNIAN JD: Serum leptin concentrations in women during gonadotropin stimulation cycles. J Reprod Med 45: 121-125, 2000. 